\title{
Winter Quarterly Meeting, 1993
}

The Winter Quarterly Meeting was held at the Cavendish Conference Centre, London on 26 and 27 January 1993 under the Presidency of Professor A. C. P. Sims.

\section{Business meeting}

The business meeting was held on 27 January attended by 70 members of the College.

\section{Minutes}

The minutes of the Autumn Quarterly Meeting held at the Birmingham Metropole Hotel, National Exhibition Centre, Birmingham on 15 October 1992 were approved and signed.

\section{Registrar's report}

Since October, there has been considerable activity within the College.

The Tomlinson Report on Health Care and Medical Education will have important implications, not only for those of us who work and live in London but repercussions or perhaps after-shocks are already being felt as far afield as Glasgow and Manchester. Despite the tendency to cause division among all in medicine, the opportunity arises for innovative practice of psychiatry - particularly directed towards those who are in some way deprived.

The man in the lion's den just before New Year exemplifies the sort of person not now getting all the appropriate care. A recommendation has been made concerning a Community Supervision Order which has been passed by Council and is available now for further discussion.

Two more important reports were also discussed by this month's meeting of Council. They were on 'Shared Care' with general practitioners and those with severe disability arising out of mental illness.

1993 has started well and we all look for an improvement on 1992.

Professor Ann Gath

\section{Election and Introduction of Honorary Fellow}

The Rt Hon Lord Justice Butler-Sloss was unanimously welcomed to the Honorary Fellowship.
The Rt Hon Dame Ann Elizabeth Oldfield ButlerSloss, DBE, PC (introduced by Professor Israel Kolvin)

It is a source of particular pleasure and a considerable honour for me to introduce the Rt Hon Dame Ann Elizabeth Oldfield Butler-Sloss as an Honorary Fellow of the Royal College of Psychiatrists. She has distinguished herself in the judiciary and has introduced a humane dimension to the practice of law in relation to children and families; in so doing, she has impressed social, medical and political opinion. Dame Elizabeth is essentially modest, tending to keep her own counsel and divulging little about herself as the Judge, about her personality and formative family influences. I have therefore had to become an 'investigative journalist' in order to obtain at least a prècis of her achievements.

She has an unrivalled legal pedigree that extends over four generations; her grandfather was a solicitor and subsequently Under-Sheriff of Norwich; her father had a successful practice at the bar, took silk and in due course became a popular High Court Judge; her late brother, Michael Havers, was a barrister, and member of Parliament, became Attorney General and, eventually, Lord Chancellor. Dame Elizabeth was a pupil at 1 Mitre Court in Inner Temple, barristers' chambers that have had a high profile for family work for the last half-century and with a tradition for producing a succession of silks and High Court judges; and this was her legal training and stamping ground. She married a barrister, Joseph Butler-Sloss, who became a High Court Judge in Kenya; and her daughter has also entered the legal profession. Obviously, there were strong family influences on the legal side, but the influences were not restricted to the law - as is well known, the family interests and careers extended to politics and the theatre.

When one chats informally to Dame Elizabeth, it soon becomes apparent that beneath her shy exterior is a warm personality, and this is reflected as well in her devotion to her family. One wonders which of the influences-legal, political or general family - was the origin of her driving motivation; or whether perhaps it was a combination of these, enhanced by the characteristics of her own personality.

In an era of difficulty for women at the Bar, Dame Elizabeth made spectacular progress, becoming a Probate Registrar at the Principal Registry, Somerset House, which became the Family Division, hearing family cases. In this post, she was not only a 
success, but showed a streak of common sense and understanding that she incorporated into the practice of law. As a consequence, she was promoted to High Court Judge - and in law terms this was a quantum leap. Here, too, she demonstrated three qualities previously shown in the Registry; first, she showed compassion and an ability to understand not only the feelings of people under stress, but also how to communicate with them; second, this compassion was tempered by good sense, realism and a nononsense approach; third she had the unusual ability to de-fuse difficult Court situations by the use of a dry sense of humour. It is important not to omit, nor to forget her previous contributions to legal authorship through editing the centrally important works Phipson on Evidence; and an editor of Supreme Court Practice.

In the face of a major crisis of confidence in relation to child sexual abuse in the Cleveland community, the Government set up an Inquiry and wisely appointed Dame Elizabeth to head this Inquiry. The qualities that I have mentioned that she had previously shown in family work made her an obvious and admirable choice. In Cleveland, those of us who were invited to help with the Inquiry were witnesses to the high, unfettered emotions with which she was confronted, emanating not only from the multiplicity of professionals caught up in the crisis, some of whom often felt under threat, but also from families who were dismayed by the awesome potential consequences of the allegations. Dame Elizabeth coped with all of this for 74 days with unfailing good humour, and ensured that the parents felt neither gagged nor unheard. Her report was a model of clarity, good sense and moderation, and has proved widely influential. In it Dame Elizabeth showed an ability to analyse and clarify a range of complex and powerful clinical and psychological issues in a humane way. Throughout the report, it is evident that putting children first is viewed as paramount and is embodied in her way of thinking.

Cleveland was a potential professional watershed. Nevertheless, in this she excelled, showing all the attributes of a first-class lawyer - clarity of mind, logical thought, and above all an unusual depth of understanding of human behaviour and frailty, and the needs of those scarred and traumatised by their experiences. In addition, in the midst of that maelstrom of emotion and sense of revulsion about abusers, Mrs Justice Butler-Sloss still had the objectivity, compassion and vision to be able to emphasise the crucial importance of the need to provide psychotherapy or other forms of help for abusers.

Her success in this assignment was rewarded with promotion to the Court of Appeal as a Lord Justice, the only woman among 29 men. As always, she has risen to the challenge with unflagging enthusiasm, and has taken in her stride everything with which she has been confronted.

After Cleveland, she proved enthusiastic about the philosophy and proposals of the 1989 Children Act and actively contributed to the education and training in this context, not only of the judiciary but also of members of other specialist groups, from social services, paediatrics and psychiatry. Indeed she has not only taken part in educating psychiatrists, but has allowed herself to be educated by them with regard to child and family psychiatry. Dame Elizabeth has shown that the law is not only capable of entering into a dialogue with professionals who are interested in the welfare of children, but is more than willing to do so. As she is someone who is dedicated to families and family life, it is not surprising to learn that she is a Trustee - and actively supports the work - of the Family at Risk Charity (of the Institute of Family Therapy); she is also a Patron of the Peper Harow Foundation.

Dame Elizabeth has a long acquaintance with medicine through her membership of the MedicoLegal Society, and a long acquaintance as well with child and family psychiatry, both legally and, as I have mentioned, as a trainer. Those of us who have held her in awe when giving evidence in the High Court, have been charmed by her accessibility, friendliness and helpfulness in informal or formal teaching situations.

Over the last five years, Dame Elizabeth's manifold skills and achievements have received national and international acclaim. She has been honoured by many institutions - she is an Honorary Doctor of Law of Hull, Bristol, Keele, Exeter and Brunel Universities, an Honorary member of the British Paediatric Association; and a Fellow both of the Royal College of Physicians, and the Royal Society of Medicine. She was made a Dame of the British Empire in 1979.

Mr President, today it is our turn to honour someone who has done so much for children at risk and for their families. Thus the award that we are bestowing today is our way of thanking Dame Elizabeth for her commitment to social, psychological and humanitarian issues on behalf of children at risk and families under stress and for ensuring that these issues are widely understood by the legal profession, by politicians, by social and medical agencies and by the general public. The enlightened principles that she has identified are those that our College, too, holds dear. Mr President, I ask you and the Royal College of Psychiatrists to welcome as an Honorary Fellow, Dame Ann Elizabeth Oldfield Butler-Sloss. 